\title{
Prognostyczne czynniki ryzyka nieszczelności zespolenia po resekcji przedniej u chorych na raka odbytnicy: kiedy zabezpieczająca stomia jest rzeczywiście potrzebna? Przegląd piśmiennictwa omawiającego 15457 chorych
}

\author{
Andrzej Rutkowski, Tomasz Olesiński, Leszek Zając
}

Identyfikacja czynników ryzyka wystąpienia objawowej nieszczelności zespolenia (NZ) po resekcji przedniej u chorych na raka odbytnicy.

Systematyczny przegląd piśmiennictwa dostępnego w bazie literaturowej PubMed, opublikowanego w okresie od 1 stycznia 2000 r. do 30 czerwca 2013 r. Selekcja wstępna polegała na zapoznaniu się z abstraktami wszystkich prac, zidentyfikowanych według słów kluczowych: resekcja przednia, nieszczelność zespolenia, czynniki ryzyka. Selekcja szczegółowa oparta była na zapoznaniu się z pełnym tekstem publikacji. Z analizy wyłączono prace dotyczące: resekcji laparoskopowych, stomii prewencyjnej, odległych wyników onkologicznych, jakości życia, techniki operacyjnej, operacji ze wskazań innych niż rak odbytnicy oraz metaanalizy, przeglądy piśmiennictwa i prace oparte na małym liczebnie materiale (< 100 chorych). Ostatecznie analizę oparto na 26 publikacjach.

Analizowano 53 parametry znane w okresie przed operacją i występujące śródoperacyjnie, które mogły być potencjalnie związane z ryzykiem NZ. Spośród nich 10 analizowanych parametrów okazało się niezależnym czynnikiem ryzyka nieszczelności w co najmniej 2 doniesieniach. Były to: płeć męska, wiek $\geq 60$ lat, guz $\leq 10 \mathrm{~cm}$ od brzegu odbytu, radioterapia przedoperacyjna, palenie tytoniu, cukrzyca, niskie położenie zespolenia, utrata krwi, przetoczenie krwi oraz powikłania śródoperacyjne.

Najczęściej określanymi czynnikami ryzyka NZ jest niskie położenie guza i zespolenia, płeć męska, radioterapia przedoperacyjna oraz utrata i transfuzja krwi. Sama identyfikacja czynników ryzyka nie pozwala jednak sprecyzować, kiedy wyłonienie zabezpieczającej stomii jest faktycznie niezbędne. W tym celu konieczne są dalsze prospektywne badania kliniczne.

Prognostic risk factors of anastomotic leakage following anterior resection in patients with rectal cancer: when is a protective stoma needed? Literature review of 15457 patients

Identification of the risk factors of symptomatic anastomotic leakage $(A L)$ after anterior resection in patients with rectal cancer.

A review was made of the literature from 1 January 2000 to 31 December 2013. Studies were identified by an electronic search of the PubMed database with the keywords "anterior resection, anastomotic leakage, risk factors". Only English-language studies were included. These focused on laparoscopic resection, quality of life, protective stoma and surgery technique, 'non rectal' cancer, oncological outcomes were excluded. Studies based on small numbers of patients (which we define as fewer than 100) were also excluded from the review, which is based on an analysis of data from 26 publications.

Klinika Gastroenterologii Onkologicznej

Centrum Onkologii — Instytut im. Marii Skłodowskiej-Curie w Warszawie 
The literature review identified 53 preoperative and intraoperative factors which could be potentially associated with the risk of AL. Among them, 22 have been identified as an independent risk factors for leaks in at least one publication and 10 risk factors in more than one study. The most important factors relating to anastomotic leakage were: male gender, age $\geq 60$ years, tumor located $\leq 10 \mathrm{~cm}$ from the anal verge, preoperative radiotherapy, smoking, diabetes, low level of the anastomosis, blood loss, blood transfusion and intraoperative complications.

The identification of risk factors of AL alone does not allow to indicate precisely when the construction of a protective stoma is indeed mandatory. Thus, further prospective studies are recommended.

NOWOTWORY Journal of Oncology 2014; 64, 5: 401-414

Słowa kluczowe: resekcja przednia, nieszczelność zespolenia, czynniki ryzyka

Key words: anterior resection, anastomotic leakage, risk factors

\section{Wstęp}

Nieszczelność zespolenia (NZ) okrężnico-odbytniczego jest jednym z najpoważniejszych powikłań pooperacyjnych po resekcji przedniej u chorych na raka odbytnicy. Całkowity odsetek raportowanych nieszczelności wynosi od około $2 \%$ do nawet 23\%, przyjmuje się jednak, że problem ten dotyczy około 11-12\% chorych po resekcji przedniej [1]. Wykazano, iż wyłonienie zabezpieczającej stomii zmniejsza ryzyko występowania objawów klinicznych nieszczelności zespolenia i odsetek reoperacji spowodowanych nieszczelnością [2-5], stąd większość niskich zespoleń zabezpieczanych jest stomią. Wyniki holenderskiego audytu (Dutch Surgical Colorectal Audit —DSCA), obejmującego grupę 988 chorych po resekcji przedniej, operowanych w 2010 roku, wykazały, że w 70\% przypadków zespolenie zabezpieczano stomią prewencyjną [6]. Wyniki te porównano z danymi badania TME (TME-trial; $\mathrm{n}=891$; lata 1996-1999) [7]. Stwierdzono, iż w okresie od 2010 roku znacząco wzrósł odsetek wykonywanych stomii prewencyjnych (57\% vs 70\%; $\mathrm{p}<0,001)$, fakt ten nie miał jednak wpływu na zmniejszenie odsetka nieszczelności ( $11,4 \%$ vs 12,1\%; $p=0,640)$. Powstaje zatem pytanie, czy w świetle tych danych wyniki opublikowanych wcześniej badań i przeglądów piśmiennictwa są wystarczającym argumentem za tym, aby podczas niskiej resekcji przedniej rutynowo wyłaniać prewencyjną stomię. Jeżeli bowiem za miarę postępu przyjąć, iż zmierzamy do personalizacji leczenia w taki sposób, aby było ono optymalne dla konkretnego chorego, to naturalnym wydaje się dążenie do sprecyzowania roli i znaczenia czynników ryzyka NZ, które byłyby pomocne dla chirurga w podjęciu decyzji o wyłonieniu bądź zaniechaniu wyłonienia zabezpieczającej stomii.

\section{Prognostyczne czynniki ryzyka nieszczelności zespolenia po resekcji przedniej odbytnicy}

Skupiając się na poszukiwaniu czynników predysponujących do wystąpienia NZ po resekcji przedniej, dwóch współautorów (AR i TO) przeszukało niezależnie od siebie bazę piśmiennictwa PubMed według słów kluczowych: anterior resection, anastomotic leakage, risk factors. Wyszukiwa- nie ograniczono do prac opublikowanych w całości w języku angielskim w okresie od 1 stycznia 2000 r. do 31 grudnia 2013 r. Selekcja wstępna polegała na zapoznaniu się ze streszczeniami 100 prac (AR, TO, LZ). Kryteria wyłączenia publikacji $z$ analizy przedstawiono na rycinie 1 . Wyodrębniono 64 publikacje, które poddano analizie szczegółowej, polegającej na zapoznaniu się z pełnym tekstem doniesienia (AR, TO, LZ). W rezultacie wyselekcjonowano 23 publikacje. Dobór prac przedyskutowano w gronie wszystkich współautorów i dołączono jeszcze 3 prace znalezione podczas przeglądu piśmiennictwa wcześniej wyselekcjonowanych artykułów. Ostatecznie oparto się na 26 pozycjach piśmiennictwa [8-33], które analizowano pod kątem wyodrębnienia znanych przed operacją oraz występujących w trakcie operacji czynników, mających znaczenie prognostyczne dla wystąpienia NZ. Autorzy wyselekcjonowanych prac badali ogółem 53 czynniki ryzyka (tab. I). Wyniki przeprowadzonych przez nich analiz przedstawiono $w$ tabeli II.

\section{Wiek chorego}

Jung i wsp. [17] wykazali znacząco większy odsetek klinicznie jawnych nieszczelności u chorych $\geq 60$ roku życia (3,6\% vs 1,6\%; $p=0,021 ; \mathrm{HR} 2,32 ; 95 \% \mathrm{Cl} 1,12-7,83)$. Podobne wyniki przedstawili Kumar i wsp. [25]. Spośród 20 chorych w wieku > 60 lat nieszczelność zaobserwowano u 7 (35\%). U młodszych chorych nieszczelność wystąpiła w 9 przypadkach (10\%); $p=0,004 ;$ OR 7,23. Zgoła odmienne wyniki prezentują autorzy innych badań, w których młodszy wiek (<65 lat) okazał się być jednym z czynników ryzyka, ale tylko $w$ analizie jednoczynnikowej [20, 32]. Gdyby jednak przyjąć, że wiek $\geq 60$ lat predysponuje do wystąpienia objawowej nieszczelności, to w praktyce klinicznej czynnik ten traci na znaczeniu, gdyż większość chorych zapada na raka odbytnicy w siódmej dekadzie życia.

\section{Płeć męska}

Mathiessen i wsp. [9] wykazali większe ryzyko NZ u mężczyzn (17\% vs 8\%; $p=0,009)$. Podobne wyniki przyniosły dane z Norweskiego Rejestru Raka Odbytnicy (Norwe- 


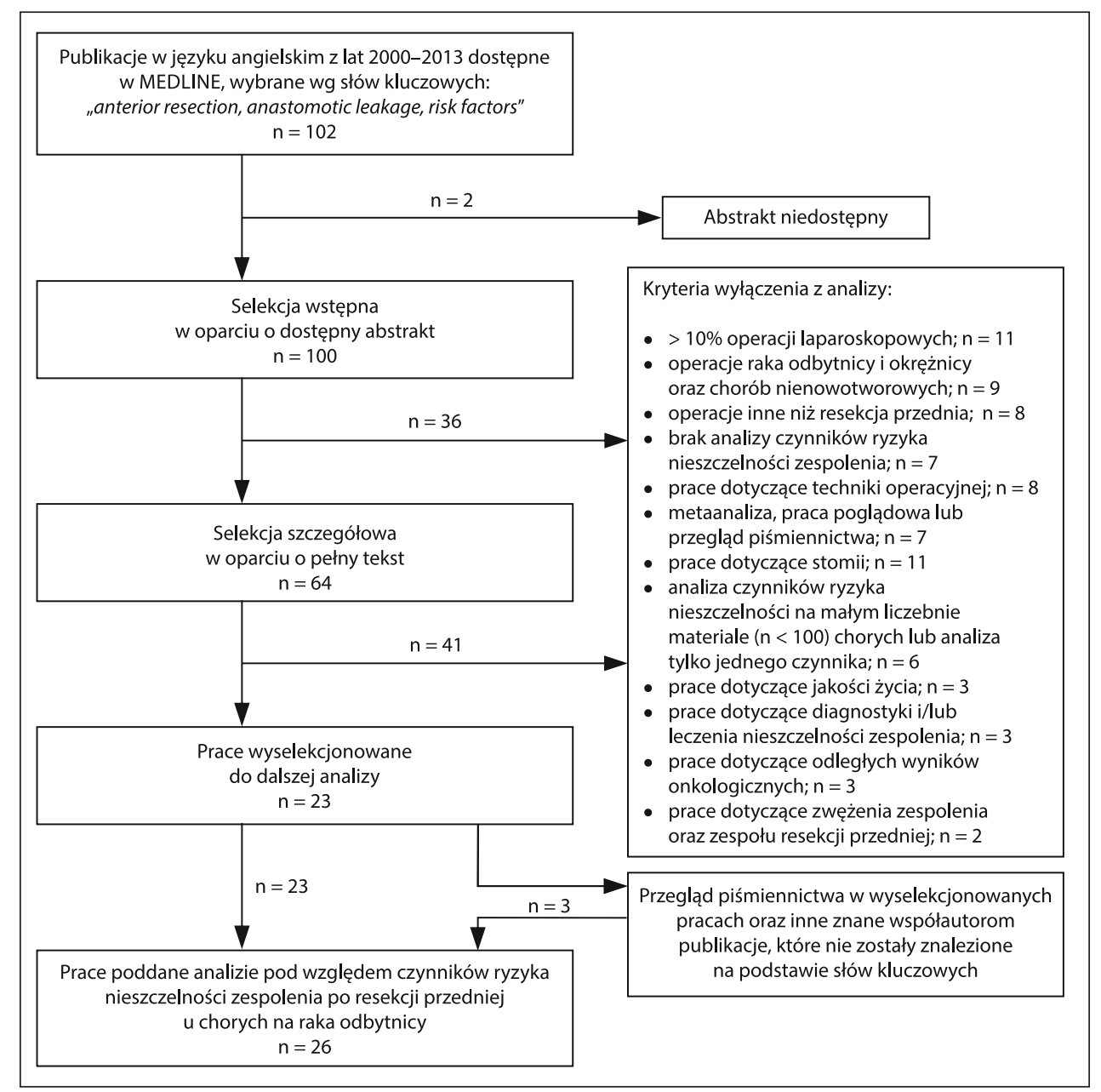

Rycina 1. Selekcja publikacji

gian Rectal Cancer Registry) oraz Duńskiego Rejestru Raka Jelita Grubego (Danish Colorectal Cancer Register). W pierwszym odsetek nieszczelności u mężczyzn — w porównaniu z kobietami - wynosił 13\% vs 9,8\% ( $p=0,010$; OR 1,6; 95\%Cl $1,1-2,3)[11]$. W drugim - 13,7\% vs 7,1\% ( $p<0,001$; OR $3,1 ; 95 \% \mathrm{Cl} 1,8-5,4)$ [18]. Z kolei w badaniu opublikowanym przez Lee i wsp. [16] zaobserwowano 5,4\% nieszczelności u mężczyzn, zaś u kobiet zaledwie 2,4\% ( $p=0,041$; RR 2,01; $95 \% \mathrm{Cl} 1,03-3,91$ ). W badaniu Junga i wsp. [17] odsetek NZ u mężczyzn był trzykrotnie większy niż u kobiet: 3,4\% vs $1,1 \%$ ( $p<0,05$; HR 2,92; 95\%Cl 1,18-7,22). Law i wsp. [8] w prospektywnym badaniu analizowali czynniki ryzyka nieszczelności u chorych po niskiej resekcji przedniej techniką TME. Płeć męska była jedynym istotnym czynnikiem ryzyka. Ponadto mniejsze ryzyko NZ występowało u chorych z wyłonioną stomią zabezpieczającą, ale też tylko u mężczyzn ( $p=0,001)$. W trzech innych badaniach płeć męska wiązała się z większym ryzykiem nieszczelności na równi z niskim położeniem zespolenia $[15,31]$ lub guza $(\leq 7 \mathrm{~cm})$ [21]. Mimo iż długa i ciasna miednica u mężczyzny może utrudnić preparowanie tkanek pod kontrolą wzroku i w re- zultacie zmniejszyć szanse na wykonanie resekcji z przywróceniem ciągłości przewodu pokarmowego, to jednak trudno racjonalnie wytłumaczyć, dlaczego płeć męska miałaby wpływać na trudności z wygojeniem prawidłowo wykonanego zespolenia.

\section{Palenie tytoniu}

Bertelsen i wsp. [18] wymieniają palenie tytoniu jako jeden z niezależnych czynników ryzyka NZ. Inni autorzy w wieloczynnikowej analizie wykazali znaczenie palenia tytoniu dla ryzyka nieszczelności i śmiertelności okołooperacyjnej [13]. Trudno powiedzieć, w jakim mechanizmie palenie tytoniu zaburza gojenie zespolenia jelitowego. Być może ma na to wpływ zaburzenie procesu wytwarzania kolagenu, obserwowane u palaczy [34]. Niezależnie jednak od przyczyny czynnik ten należy brać pod uwagę w ocenie ryzyka wystąpienia nieszczelności.

\section{Choroby współwystępujące}

Choroby układu krążenia to najczęściej przewijające się jednostki chorobowe, które brane są pod uwagę jako 
Tabela I. Czynniki analizowane przy ocenie ryzyka nieszczelności zespolenia po resekcji przedniej raka odbytnicy

\begin{tabular}{|c|c|}
\hline Czynniki ryzyka nieszczelności & Pozycje piśmiennictwa \\
\hline \multicolumn{2}{|l|}{ znane przed operacją } \\
\hline - wiek & {$[8,10-14,16-33]$} \\
\hline — płeć męska & {$[8-26,28-33]$} \\
\hline — odległość guza od brzegu odbytu & {$[8,10,13,14,17-21,23-26,28,30,32]$} \\
\hline - ECOG & {$[27,33]$} \\
\hline$-\mathrm{BMI}$ & {$[9,13,14,16,18,20,22-24,26,27,30-32]$} \\
\hline — utrata wagi & {$[12,18]$} \\
\hline$-\mathrm{ASA}>2$ & {$[12,14-16,18,20,22,24,29,30,32]$} \\
\hline — palenie tytoniu & {$[13,14,18-20,22,23,28-30,32,33]$} \\
\hline — picie alkoholu & {$[13,14,18,32]$} \\
\hline — otyłość & [13] \\
\hline — aktywność fizyczna & [18] \\
\hline - cukrzyca & {$[12,13,18,19,21,22,28,29,31-33]$} \\
\hline — nadciśnienie tętnicze & {$[12,13,27,29,32]$} \\
\hline — choroba niedokrwienna serca & {$[12,13,20,22,27-29,32,33]$} \\
\hline - choroby płuc & {$[13,23,27,32]$} \\
\hline - anemia & {$[14,16,21,23,25]$} \\
\hline — hipoalbuminemia & {$[12,14,23,25]$} \\
\hline - trombocytopenia & [23] \\
\hline — historia chirurgiczna & [12] \\
\hline — choroby naczyniopochodne (miażdżyca) & [24] \\
\hline — przewlekła niewydolność nerek & [27] \\
\hline — zwężenie jelita & [19] \\
\hline — niedrożność & [19] \\
\hline — niewydolność narządowa & {$[10]$} \\
\hline — antybiotykoterapia & {$[12]$} \\
\hline — radioterapia przedoperacyjna & {$[9-11,13-19,24,26,28,30-33]$} \\
\hline $\begin{array}{l}\text { - leki: antykoagulanty, antagoniści wapnia, beta-blokery, inhibitory ACE, } \\
\text { sterydy }\end{array}$ & {$[29,32]$} \\
\hline \multicolumn{2}{|l|}{ występujące w trakcie operacji } \\
\hline — znieczulenie z.o. & [15] \\
\hline — niskie zespolenie ${ }^{1}$ & {$[8,9,11,12,15-17,22,26,30,31]$} \\
\hline — wielkość guza & {$[12,14,17,22,23,26,31]$} \\
\hline — resekcja en-block & {$[8,12,19,31]$} \\
\hline - technika zespolenia ${ }^{2}$ & {$[8-15,18,19,23-25,29,30]$} \\
\hline — drenaż miednicy i/lub zespolenia ${ }^{3}$ & {$[9,10,12,15,19]$} \\
\hline — uwolnienie lewego zagięcia okrężnicy & {$[23,30]$} \\
\hline — miejsce podwiązania naczyń krezkowych & {$[23,26]$} \\
\hline — rodzaj użytego staplera & {$[16,29]$} \\
\hline — brak stomii zabezpieczającej & {$[8-12,14,15,17-19,22,24,26,28,30]$} \\
\hline — utrata krwi/krwotok & {$[9,10,15,18,21,22,23,24,25,26,30,31]$} \\
\hline — powikłania śródoperacyjne & {$[9,15]$} \\
\hline — omentoplastyka zespolenia & {$[10]$} \\
\hline$-\mathrm{TME}$ & [13] \\
\hline — przygotowanie jelita & [12] \\
\hline - czas operacji & {$[9,10,12,14-16,22-26]$} \\
\hline — doświadczenie chirurga & {$[12,18,19,24]$} \\
\hline — referencyjność szpitala & [15] \\
\hline \multicolumn{2}{|l|}{ znane lub występujące po operacji } \\
\hline — morfologia guza & {$[12,14,23,25]$} \\
\hline - TNM / Dukes & {$[8-18,21-24,26,30,31]$} \\
\hline — zróżnicowanie nowotworu (cecha G) & {$[14,17]$} \\
\hline — marginesy resekcji & {$[14,19,23,25]$} \\
\hline — radykalność resekcji $(\mathrm{RO}, 1,2)$ & {$[9,11,16,19,25,28,33]$} \\
\hline — naciekanie naczyń limfatycznych & {$[16,17]$} \\
\hline — przetaczanie krwi & {$[12,14,22,23,24,27,29]$} \\
\hline - leczenie w warunkach OІOM & [15] \\
\hline
\end{tabular}

${ }^{1}$ - pojęcie różnie definiowane przez różnych autorów; ${ }^{2}$ - zespolenia ręczne, staplerowe, koniec-koniec, koniec-bok, J-pouch; ${ }^{3}$ - wyniki przeciwstawne: czynnik zwiększający lub zmniejszający ryzyko nieszczelności; OIOM — oddział intensywnej opieki medycznej 


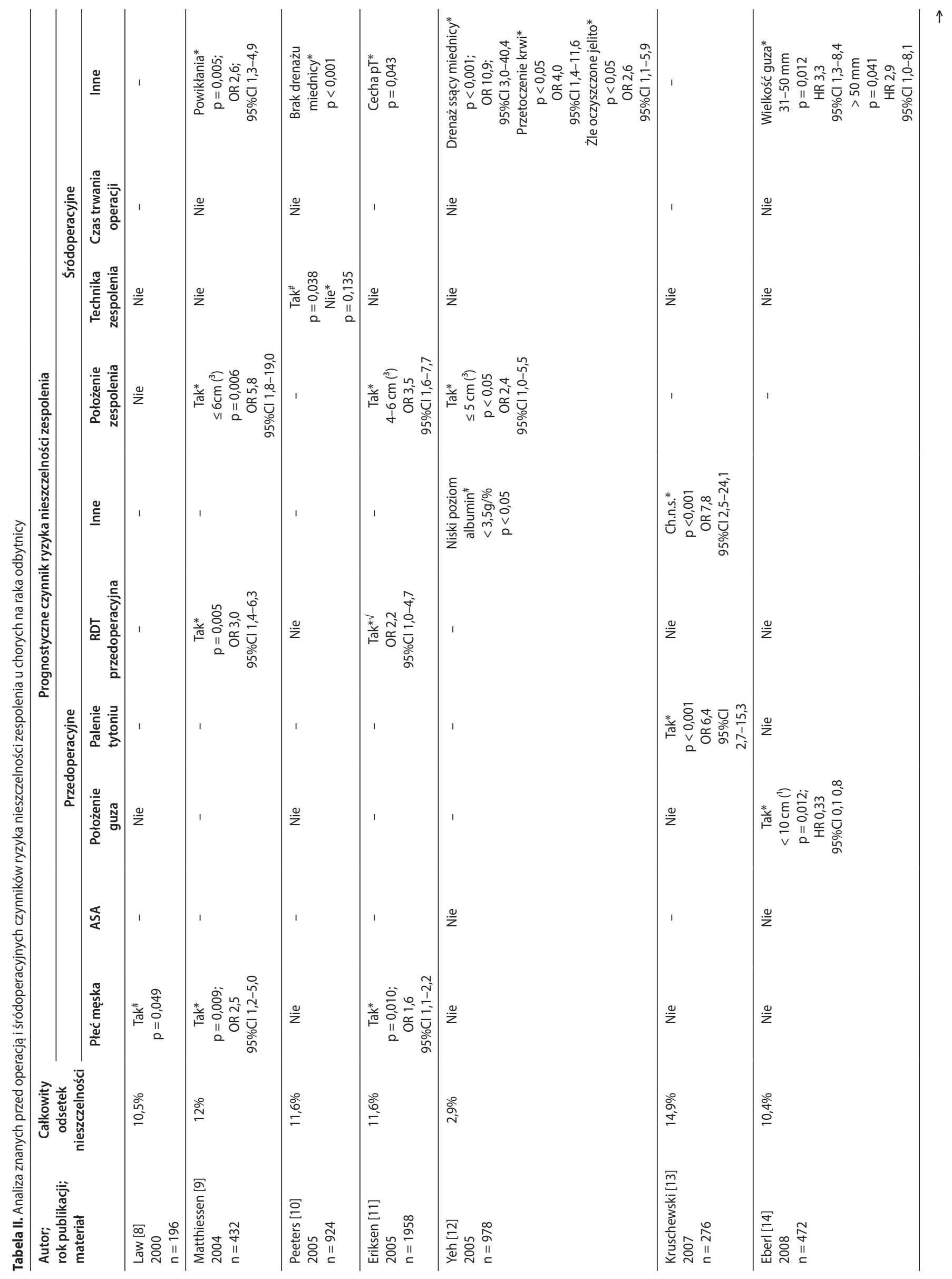




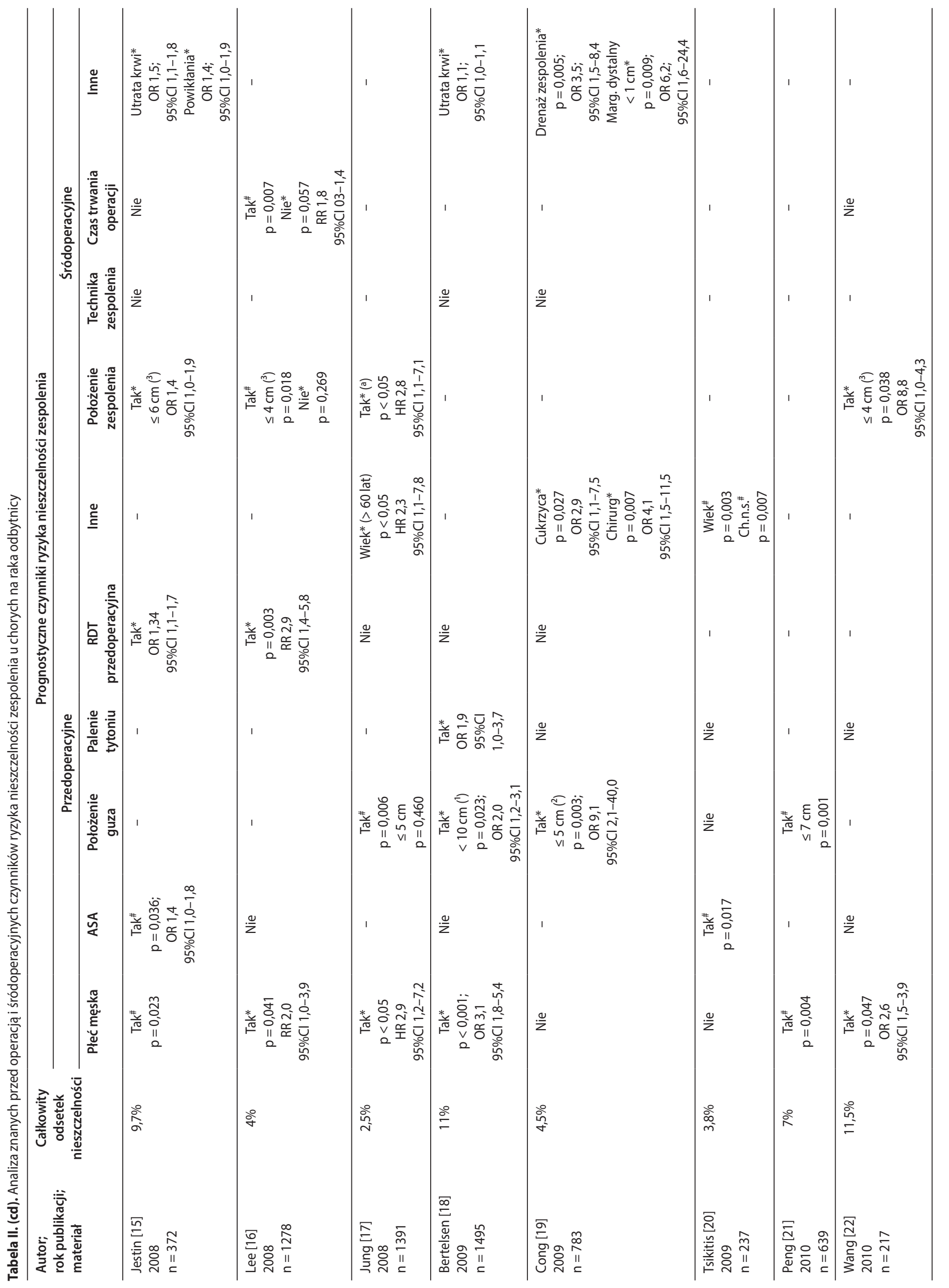




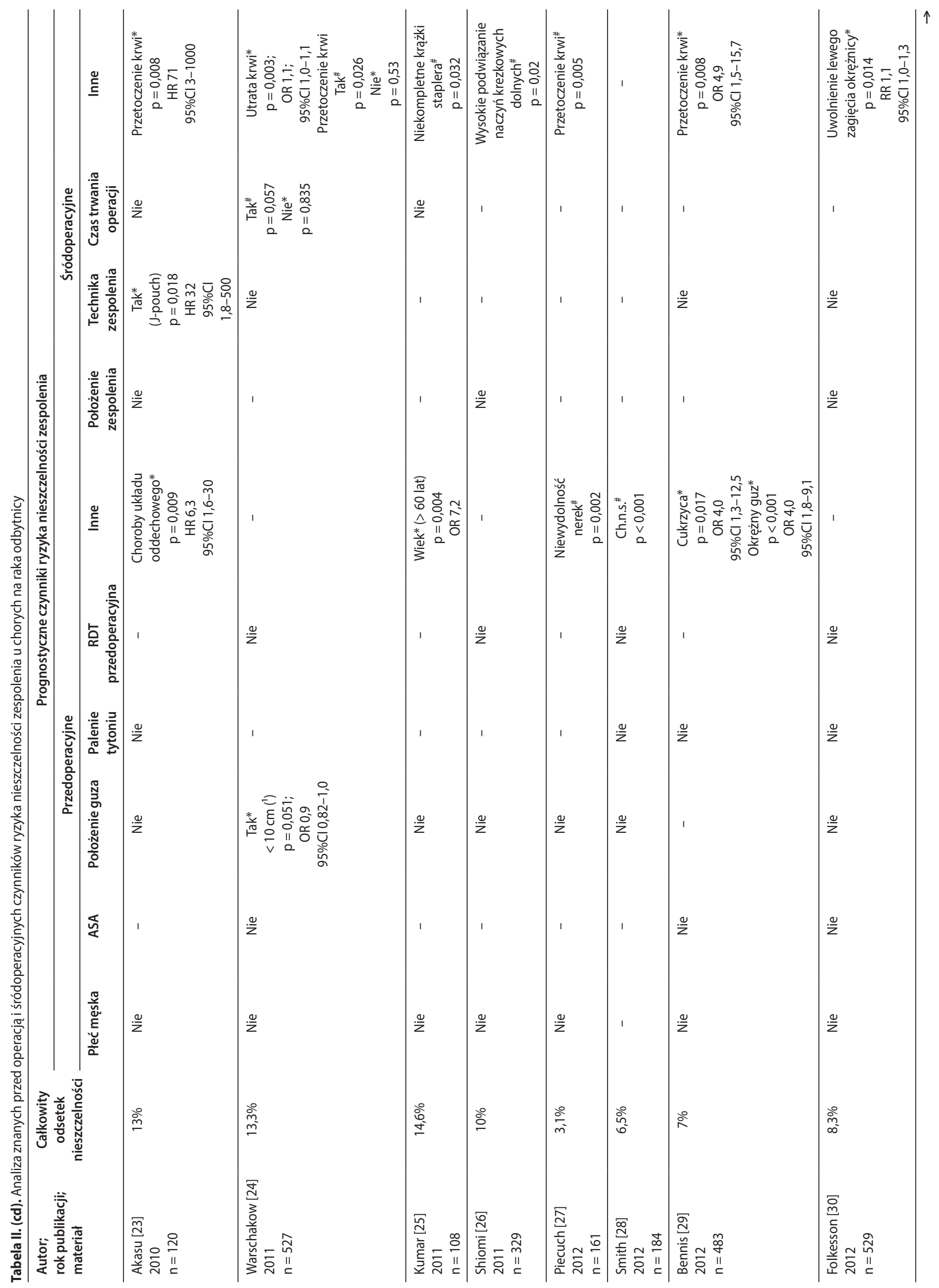


potencjalne czynniki zwiększające ryzyko NZ. Kruschewski i wsp. [13] rozpoznawali chorobę niedokrwienną serca (ch.n.s.) na podstawie zmian w EKG i/lub dodatniego wywiadu w kierunku objawów dusznicy bolesnej (angina pectoris) bądź też leków przyjmowanych przez chorego. Odsetek NZ w tej grupie wynosił $22,6 \%$, podczas gdy całkowity odsetek nieszczelności w całej badanej grupie chorych nie przekroczył 15\% ( $p<0,001 ;$ OR 7,79; 95\%Cl $2,52-24,08)$. W dwóch innych badaniach wykazano istotne znaczenie chorób układu krążenia określone przez autorów jako cardiovascular disease, ale obserwacje te dotyczyły tylko analiz jednoczynnikowych [20, 28]. Nadciśnienie tętnicze (najczęstsza w tej grupie schorzeń jednostka chorobowa) nie miało jednak wpływu na ryzyko nieszczelności $[12,13$, 27, 29, 32]. Można się domyślać, iż w przypadku chorób układu krążenia dochodzi do upośledzenia ukrwienia tkanek, co w konsekwencji może mieć znaczenie dla procesu gojenia się zespolenia. Prace, które uwzględniały choroby naczyniopochodne jako czynnik ryzyka, nie wykazały, aby miały one istotne znaczenie, chociaż choroby te dotyczyły $41-50 \%$ chorych [24, 32]. Cukrzyca była wymieniona jako niezależny czynnik ryzyka w dwóch spośród analizowanych publikacji $[19,29]$. Niestety, autorzy nie precyzują, jak długi był okres trwania choroby od rozpoznania do operacji ani nie dokonują podziału na cukrzycę typu I i typu ll. Być może ten podział nie ma w tym wypadku większego znaczenia. Wydaje się jednak, że cenną informacja byłoby określenie, czy długoletni wywiad w kierunku cukrzycy niesie za sobą większe ryzyko NZ niż świeżo rozpoznana choroba. Jedynie w jednej z prac autorzy precyzują, iż chodzi o cukrzycę wymagającą leczenia farmakologicznego [13], ale jednocześnie nie wykazuja, aby był to czynnik ryzyka $(p=0,067)$. Akasu i wsp. [23] wykazali sześciokrotnie większe ryzyko objawowej nieszczelności u chorych z zespoleniem koloanalnym w przypadku współwystępowania przewlekłej obturacyjnej choroby płuc (POCHP) lub innych chorób restrykcyjnych układu oddechowego( $p=0,009$; HR 6,3;95\%Cl 1,6-26). Przyczyn takiego stanu rzeczy dopatrywać się można w nagłych zmianach ciśnienia panującego w obrębie jamy brzusznej, występujących w trakcie silnego, przewlekłego kaszlu. Badano przy tym znaczenie przedoperacyjnego oznaczenia natężonej objętości wydechowej jednosekundowej (FEV1 \%). U $25 \%$ chorych z wartością FEV1 < 70\% wystąpiły poważne objawy NZ. Przy wartości FEV1 > 70\% podobne objawy zaobserwowano jedynie $u 4 \%$ badanych $(p=0,051)$. Inne publikacje nie wykazują, aby POCHP była istotnym czynnikiem ryzyka [13, 27]. Być może zatem obturacyjna choroba płuc przyczynia się do zwiększenia ryzyka nieszczelności, ale ma to większe znaczenie przy zespoleniach koloanalnych.

W analizowanym piśmiennictwie znalazła się tylko jedna publikacja oceniająca znaczenie przewlekłej niewydolności nerek jako potencjalnego czynnika zwiększającego ryzyko nieszczelności [27]. Wynika to prawdopodobnie z tego, iż 
tylko niewielka liczba chorych z takim rozpoznaniem jest kwalifikowana do jednoczasowej rekonstrukcji przewodu pokarmowego. Często obserwowanym objawem u chorych na raka jelita grubego jest anemia, pomimo to w żadnej z analizowanych pozycji piśmiennictwa nie wykazano, aby niski poziom hemoglobiny istotnie zwiększał ryzyko NZ [14, $16,21,23,25]$. Znanym jest również fakt większej skłonności do powikłań zakrzepowych u chorych z zaawansowaną chorobą nowotworową. W analizie jednoczynnikowej wykazano, że poziom płytek krwi niemieszczący się w grani-

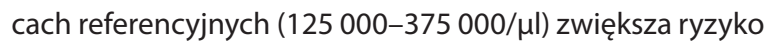
nieszczelności $(p=0,02)$ [23]. Autorzy nie precyzująjednak, czy chodzi o nadpłytkowość, czy też o trombocytopenię. W innych pojedynczych publikacjach znajdziemy odniesienie do oceny ryzyka NZ przy współwystępowaniu przewężenia jelita lub niedrożności [19] związanych z przebytymi w przeszłości operacjami [12] czy z przyjmowaniem określonych leków [12, 29, 32] (tab. I). W żadnym z tych badań nie wykazano, aby wymienione czynniki wpływały na ryzyko nieszczelności zespolenia.

\section{Hipoalbuminemia i hipoproteinemia}

Niski poziom białek i albuminy w surowicy krwi (hipoproteinemia i hipoalbuminemia) uznawany jest dość powszechnie za czynnik upośledzający gojenie ran i zespoleń jelitowych. Te obserwacje zdają się choćby częściowo potwierdzać doniesienia prezentowane przez Yeh'a i wsp. [12]. Za wartość graniczną uznano $w$ tym badaniu poziom albu$\min <3,5 \mathrm{~g} / \%$. Ebrel i wsp. [14] w odniesieniu do całkowitego poziomu białka w surowicy krwi na poziomie $\leq 7 \mathrm{~g} / \mathrm{dL}$ i > 7 g/dL nie stwierdzili różnic w odsetkach nieszczelności. Podobnie w badaniach innych autorów: obserwacje, jakoby hipoalbuminemia $<3,5 \mathrm{~g} / \mathrm{dL}$ wiązała się z większym ryzykiem NZ, nie znajdują potwierdzenia [21,25]. W odróżnieniu od tego Akasu i wsp. [23] w analizie jednoczynnikowej wykazali, że zarówno hipoalbuminemia $<3,7$ g/dL, jak i hipoproteinemia <6,3 g/dL zwiększają ryzyko NZ (odpowiednio: $\mathrm{p}=0,007 \mathrm{i} \mathrm{p}=0,039$ ). Trudno zatem jednoznacznie odpowiedzieć, jaką rolę prognostyczną co do ryzyka NZ pełni przedoperacyjne oznaczenie poziomu białka całkowitego i albumin. Wydaje się, że hipoalbuminemia i hipoproteinemia wiązać się mogą raczej z niedożywieniem chorego i jego wyniszczeniem, a w konsekwencji — z opóźnionym gojeniem ran i zespoleń.

\section{Wskaźnik masy ciała (BMI) i stan odżywienia chorego}

Podstawowym parametrem klinicznym oceniającym stan odżywienia chorego jest wskaźnik masy ciała (BMI). Mimo iż w połowie spośród analizowanych pozycji piśmiennictwa autorzy wyselekcjonowali ten czynnik jako parametr oceny ryzyka nieszczelności, to w żadnej z przeprowadzonych analiz nie stwierdzono, aby miał on istotne znaczenie
$[9,13,14,16,18,20,22-24,26,27,30-32]$. Ciekawe jest jednak spostrzeżenie, że większy (chociaż statystycznie nieistotny) odsetek NZ zanotowano u chorych z wysokim wskaźnikiem BMI $(>25-26$ kg/m²) [9, 13, 14, 22, 23]. Kruschewski i wsp. [13] wykazali $20 \%$ odsetek nieszczelności zespolenia w grupie chorych otyłych (BMl $\left.>30 \mathrm{~kg} / \mathrm{m}^{2}\right)$. Z kolei utrata wagi > 10\% masy ciała, raportowana w dwóch innych badaniach, również nie miała znaczenia dla ryzyka nieszczelności $[12,18]$. Cytowane badania miały charakter retrospektywny i z dużym prawdopodobieństwem można przyjąć, iż chorzy wyniszczeni lub ze znacznym niedożywieniem nie byli kwalifikowani do resekcji przedniej. Za to spostrzeżeniem godnym uwagi jest fakt, iż chorzy otyli mieli wyższy odsetek nieszczelności niż pozostała grupa chorych.

\section{Ocena ryzyka powikłań okołooperacyjnych według skali ASA}

Większość z omówionych powyżej czynników brana jest pod uwagę w ocenie ryzyka powikłań okołooperacyjnych opisywanych według klasyfikacji opracowanej przez American Society of Anaesthesiology (ASA). Na podstawie analizy wieloczynnikowej Jestin i wsp. [15] wymieniają stopień ASA > 2 jako jeden z niezależnych czynników ryzyka NZ i śmiertelności pooperacyjnej (HR 2,01; 95\%Cl 1,43-2,84). Podobne wyniki oparte o analizę jednoczynnikową odnotowali również Tsikitis i wsp. [20], gdzie odsetek nieszczelności u chorych ASA > 2 wyniósł 34\%. Z drugiej strony na uwagę zasługują obserwacje płynące $z$ badania opublikowanego przez Eberla i wsp. [14], w którym porównano ryzyko NZ w grupie chorych sklasyfikowanych jako ASA 1-2 z grupą ASA 3-4. Odsetek nieszczelności w obu grupach wyniósł odpowiednio 7,9\% i 13,5\% ( $p=0,052$; OR 1,82; 95\%Cl 0,99-3,34). Pomimo zaznaczającej się tendencji analiza wieloczynnikowa nie wykazała, aby stopień ASA 3-4 był istotnym czynnikiem ryzyka ( $p=0,07$; HR 1,85; 95\%Cl 0,94-3,61). Brak zatem dowodów, aby wysoki stopień ASA przekładał się bezpośrednio na ryzyko występowania izolowanego powikłania w postaci NZ.

\section{Radioterapia przedoperacyjna}

Obserwacje kliniczne zdają się wskazywać, że radioterapia przedoperacyjna (pRDT) jest istotnym czynnikiem ryzyka NZ. Matthiessen i wsp. [9] wykazali, iż pRDT wysokimi dawkami frakcyjnymi $(5 \times 5$ Gy to niezależny czynnik ryzyka ( $p=0,005 ;$ OR 3,0; 95\%Cl 1,4-6,3). Podobne wyniki prezentują Eriksen i wsp. [11], podkreślając jednak, że pRDT stosowana była w bardzo wyselekcjonowanej grupie chorych i dotyczyła zaledwie 3\% ich liczebności. Trudne do zinterpretowania są też wyniki przedstawione przez szwedzkich autorów, którzy również wskazują, iż pRDT $5 \times 5$ Gy z natychmiastową operacją znacząco zwiększa ryzyko nieszczelności (OR 1,34; 95\%Cl 1,06-1,69) [15].W badaniu tym porównano 132-osobową grupę chorych z objawową nieszczelnością 
Tabela III. Definicja niskiej resekcji przedniej (LAR) i ryzyko nieszczelności zespolenia

\begin{tabular}{lcc}
\hline Autor [pozycja piśmiennictwa] & $\begin{array}{c}\text { Kryterium przyjęte przez autorów publikacji } \\
\text { jako określenie niskiej resekcji przedniej }\end{array}$ & $\begin{array}{c}\text { Odsetek klinicznie ujawniających się } \\
\text { nieszczelności zespolenia }\end{array}$ \\
\hline Jung i wsp. [17] & zespolenie poniżej załamka otrzewnej & $1,9 \%$ \\
Lee i wsp. [16] & zespolenie poniżej załamka otrzewnej & $4 \%$ \\
Law i wsp. [8] & zespolenie w odległości $\leq 5 \mathrm{~cm}$ od brzegu odbytu & $10,5 \%$ \\
Wang i wsp. [22] & zespolenie w odległości $\leq 8 \mathrm{~cm}$ od brzegu odbytu & $11,5 \%$ \\
Eriksen i wsp. [11] & zespolenie w odległości 4-6 cm od brzegu odbytu & $13,7 \%$ \\
Mathiessen i wsp. [9] & zespolenie w odległości $\leq 6 \mathrm{~cm}$ od brzegu odbytu & $24 \%$ \\
\hline
\end{tabular}

zespolenia (cases group) z grupą 240 chorych (control group) wybraną w sposób losowy ze Szwedzkiego Rejestru Raka Odbytnicy (Swedish Rectal Cancer Registry), będących po resekcji przedniej bez NZ. W grupie badanej radioterapię zastosowano u 58\% chorych, zaś w grupie kontrolnej u 43\%, co było różnicą istotną statystycznie $(p=0,005)$. W komentarzu autorzy zauważają, iż wyniki dwóch randomizowanych badań przeprowadzonych w Szwecji przeczą tym doniesieniom [35, 36]. Za możliwą przyczynę zaobserwowanych różnic podają, że pewne kryteria wyłączenia z udziału w tych badaniach mogły mieć wpływ na obserwowany odsetek NZ. Identyczny sposób radioterapii stosowany był u chorych uczestniczących w badaniu autorów zrzeszonych w Dutch Colorectal Cancer Group, gdzie odsetek nieszczelności w grupie chorych napromienianych wyniósł 12,3\% i nie różnił się od grupy chorych nienapromienianych (10,9\%) [10]. Wyniki te są porównywalne z cytowanym już na wstępie badaniem holenderskim (TME-trial), przeprowadzonym przez tą samą grupę badaczy [7]. Lee i wsp. [16] podają, że zastosowanie przedoperacyjnej radiochemioterapii jest niezależnym czynnikiem ryzyka ( $\mathrm{p}=0,003 ; \mathrm{RR} 2,86 ; 95 \% \mathrm{Cl}$ 1,41-5,77). W przeciwieństwie do tego Jung i wsp. [17], w badaniu opartym na podobnej liczebnie grupie chorych, nie wykazali istotnych różnic ( $1,7 \%$ vs $2,6 \% ; p=0,720)$. Z przeglądu piśmiennictwa rysuje się ciekawe spostrzeżenie, że radioterapia przedoperacyjna okazywała się być istotnym czynnikiem ryzyka nieszczelności głównie w tych badaniach, gdzie pRDT stosowana była rzadko (3-16\%) $[9,11,16]$. W przeciwieństwie do tego tam, gdzie odsetek chorych napromienianych przedoperacyjni był większy (4,3-78\%), nie wykazywano istotnych różnic w odsetkach NZ [13, 14, 17-19, 24, 28, 30].

\section{Położenie guza i wysokość zespolenia}

Według ogólnie przyjętej definicji niskie położenie guza oznacza, iż dolny brzeg nowotworu znajduje się w odległości do $5 \mathrm{~cm}$ od brzegu odbytu. Tylko w jednej spośród analizowanych publikacji taka właśnie definicja niskiego położenia guza nowotworowego została uwzględniona [17]. Co więcej, był to istotny czynnik ryzyka wykazany jedynie w analizie jednoczynnikowej. Inni autorzy wskazywali, że istotne znaczenie dla ryzyka NZ ma położenie guza nowo- tworowego w odległości do 7-10 cm od brzegu odbytu bądź do $5 \mathrm{~cm}$ od poziomu linii zębatej, czyli w środkowej i dolnej części odbytnicy [14, 18, 19, 21, 24]. W odróżnieniu od tego znacznie trudniej znaleźć spójną definicję, co oznacza niskie położenie zespolenia, czyli co należy rozumieć przez pojęcie: niska resekcja przednia. Istnieją wystarczająco silne dane na poparcie stwierdzenia, iż ryzyko NZ jest tym większe, im niżej położone jest zespolenie. Matthiessen i wsp. [9] raportują 24\% nieszczelności przy zespoleniu położonym w odległości $\leq 6 \mathrm{~cm}$ od brzegu odbytu, $13 \%$ przy położeniu w odległości 6,5-10 cm i zaledwie 4\%, gdy zespolenie znajduje się w odległości 10,5-15 cm ( $p<0,001)$. Eriksen i wsp. [11] podają z kolei 15,6\% nieszczelności przy zespoleniu $\leq 3 \mathrm{~cm} ; 13,7 \%$ przy $4-6 \mathrm{~cm} ; 7,6 \%$ przy $7-9 \mathrm{~cm}$ i 4,8\% przy położeniu zespolenia w odległości $\geq 10 \mathrm{~cm}$ od brzegu odbytu $(p<0,001)$. Liu i wsp [31] dokonują podziału ze względu na poziom zespolenia na trzy grupy: $\leq 3 \mathrm{~cm}$, 4-5 cm i $>5 \mathrm{~cm}$ od brzegu odbytu. Odsetek obserwowanych NZ wyniósł odpowiednio: 15,7\%, 8,2\% i 3,4\% ( $p<0,001)$. Inni autorzy w zależności od położenia zespolenia w odległości $\leq 4 \mathrm{~cm}$ i $>4 \mathrm{~cm}$ raportują odsetek nieszczelności na poziomie 13,8\% i 2,3\% ( $p=0,035)$ [22]. Dane przedstawione w tabeli III pozwalają zorientować się, jak różne mogą być wyniki dotyczące odsetka NZ po niskiej resekcji przedniej w zależności od tego, jak autorzy doniesienia definiują ten typ operacji. Wyniki analizowanego piśmiennictwa wydają się wskazywać, że jako kryterium określające niskie położenia zespolenia (i jako definicje niskiej resekcji przedniej) należałoby przyjąć odległość $\leq 6 \mathrm{~cm}$ od brzegu odbytu [9, $11,12,15-17,22]$

\section{Utrata krwi, krwawienie i inne powikłania śródoperacyjne}

Bertelsen i wsp. [18] wykazali, że średnia objętość utraconej śródoperacyjnie krwi w grupie chorych z NZ była istotnie większa niż u chorych bez nieszczelności (odpowiednio: mediana $600 \mathrm{ml}$ vs $400 \mathrm{ml}$; $<0,0001$ ). Bardziej precyzyjnych informacji można się było spodziewać po analizie dotyczącej okołooperacyjnego przetaczania krwi, gdzie objętość transfuzji jest dokładnie określona. Yeh i wsp. [12] wykazali, że ryzyko nieszczelności było tym większe, im większa objętość krwi musiała być przetoczona: 1-3 jedn.: 
OR 3,98 (95\%Cl 1,35-11,61); $\geq 4$ jedn.: OR 10,94 $(95 \% \mathrm{Cl}$ 2,96-40,44). Inni autorzy wykazali 25,7\% nieszczelności u chorych wymagających śródoperacyjnego przetoczenia $900 \mathrm{ml}$ krwi oraz 17,1\% przy transfuzji $600 \mathrm{ml}$, ale — niezależnie od przetoczonej objętości — nie potwierdzono, aby był to niezależny czynnik ryzyka $(p=0,085)$ [24]. Ci sami autorzy w analizie wieloczynnikowej wskazują jednak na znaczenie śródoperacyjnej utraty krwi, ale dopiero wówczas, gdy wynosi ona około $1500 \mathrm{ml}$, co w praktyce oznacza masywny krwotok. Liu i wsp. [31] wykazali istotnie większe ryzyko NZ już przy utracie $200 \mathrm{ml}$ krwi ( $p=0,045)$. Inne badania, mimo iż wskazują, że śródoperacyjna utrata i/lub konieczność przetoczenia krwi wiążą się ze wzrostem ryzyka $\mathrm{NZ}$, to brakuje w nich sprecyzowania, jaka objętość utraty bądź transfuzji jest w tym wypadku wartością graniczną [15, 23, 27, 29]. Matthiessen i wsp. [9] wykazali, że powikłania śródoperacyjne to niezależny czynnik ryzyka nieszczelności ( $p=0,005 ;$ OR 3,0; 95\%Cl 1,4-6,3). Za powikłania śródoperacyjne uznano $w$ tym badaniu: niepełne krążki staplera, dodatni wynik próby szczelności zespolenia, jatrogenną perforację guza bądź jelita, uszkodzenie pochwy, pęcherza moczowego bądź moczowodu oraz krwotok śródoperacyjny w objętości $\geq 2000 \mathrm{ml}$. Z kolei Jestin i wsp. [15], mówiąc o istotnym znaczeniu powikłań śródoperacyjnych, wiążą je z problemami zaistniałymi przy wykonywaniu zespolenia (np. nieprawidłowa działanie staplera, niekompletne krążki, dodatnia próba szczelności itp.). Zarówno krwawienie śródoperacyjne, jak i każde inne powikłanie, do którego dojść może w trakcie zabiegu, przedłużają czas trwania operacji. W żadnym z analizowanych badań nie wykazano, aby czas trwania operacji był niezależnym czynnikiem ryzyka. Jedynie w dwóch publikacjach czas trwania zabiegu (> 120 min) wiązał się z większym odsetkiem NZ, ale tylko w analizie jednoczynnikowej $[16,24]$.

\section{Inne czynniki ryzyka nieszczelności zespolenia}

Jednym z czynników, który może wpływać na trudności techniczne zaistniałe $w$ trakcie operacji, a pośrednio i na ryzyko powikłań śródoperacyjnych, jest wielkość guza nowotworowego. Eberl i wsp. [14] wykazali związek pomiędzy wielkością guza a ryzykiem nieszczelności (tab. II). W przeciwieństwie do tego Wang i wsp. [22], gdy analizowali wyniki resekcji guzów o wielkości $>5 \mathrm{~cm}$ i $\leq 5 \mathrm{~cm}$, nie stwierdzili różnic (13,7\% vs 10,8\%). Kolejni autorzy zwrócili uwagę, iż większy odsetek nieszczelności występuje po resekcji guzów zajmujących > 75\% obwodu jelita (31\% vs 10\%; $p=0,033$ ) [23]. Pośród innych śródoperacyjnych czynników, które mogą mieć wpływ na ryzyko NZ, jest złe przygotowanie jelita do zabiegu (OR 2,58; 95\%Cl 1,10-5,88) [12]. Za to w żadnym badaniu nie wykazano, aby rozszerzenie zakresu operacji o resekcje innych narządów lub innych odcinków przewodu pokarmowego wiązało się ze zwiększeniem ryzyka NZ $[8,12,19]$.

\section{Jak zapewnić optymalne warunki do wygojenia zespolenia? Sposób rekonstrukcji przewodu pokarmowego}

Hallböök i wsp. [37] wykazali, że zespolenie koniec-do-końca wiąże się z większym odsetkiem NZ w porównaniu z zespoleniem ze zbiornikiem jelitowym typu,J-pouch" (15\% vs $2 \% ; p=0,03)$. W innych randomizowanych badaniach wykazano podobny odsetek nieszczelności po zespoleniach bok-do-końca w porównaniu z zespoleniem J-pouch (10\% vs 8\%) [38], ale wyraźną przewagę rekonstrukcji ze zbiornikiem J-pouch w porównaniu z koloplastyką [39]. Tymczasem w żadnej $z$ analizowanych pozycji piśmiennictwa nie wykazano, aby zespolenie ze zbiornikiem jelitowym istotnie zmniejszało ryzyko nieszczelności [10, 12-15, 18, 19, 29, 30]. Co więcej, autorzy jednej z publikacji w modelu analizy wieloczynnikowej wykazali, iż ten typ zespolenia wiązał się z większym ryzykiem NZ w porównaniu z zespoleniem koniec-do-końca [23]. Z kolei Peeters i wsp. [10] w analizie jednoczynnikowej wskazują na korzyść zespolenia ze zbiornikiem w porównaniu z zespoleniem koniec-do-końca. Nie stwierdzono różnic w odsetkach NZ po zespoleniach ręcznych w porównaniu ze staplerowymi [8-11,25], jak również przy porównaniu zespoleń bok-do-końca i koniec-do-końca $[10,15,24,29,30]$. Można uznać, że w przypadku wykonywania niskiej resekcji przedniej najbardziej narażonym na nieszczelność jest zespolenie koniec-do-końca, chociaż paradoksalnie jest ono wykonywane najczęściej.

\section{Uruchomienie lewego zagięcia okrężnicy i miejsce podwiq̨zania naczyń krezkowych}

Do wykonania bezpiecznego zespolenia niezbędne jest uzyskanie odpowiednio długiego odcinka jelita, aby po jego wykonaniu nie dochodziło do napięcia ani w miejscu zeszycia jelita, ani w naczyniach drenujących sprowadzony do miednicy odcinek okrężnicy. Nadal nierozwiązaną przy tym kwestią pozostaje optymalny poziom podwiązania naczyń krezkowych dolnych [40]. Obowiązującą zasadą pozostaje wykonanie zespolenia bez napięcia, na dobrze ukrwionych odcinkach jelita, co przy niskich zespoleniach wręcz wymusza uwolnienie lewego zagięcia okrężnicy i nierzadko wysokie podwiązanie naczyń okrężniczych lewych. Niestety, tylko nieliczni autorzy uwzględnili te czynniki w analizie ryzyka nieszczelności [23, 30]. Paradoksalnie, w pojedynczych badaniach uwolnienie lewego zagięcia związane było z większym ryzykiem NZ, podobnie jak wysokie podwiązanie naczyń krezkowych dolnych [26, 30]. Na podstawie tych pojedynczych doniesień nie można jednak wyciągać żadnych ogólnych wniosków.

\section{Drenaż miednicy i zespolenia}

$\mathrm{U}$ chorych uczestniczących w wieloośrodkowym badaniu klinicznym (Dutch TME trial) brak drenażu miednicy wiązał się z wysokim odsetkiem NZ (23,5\% vs 9,6\%; RR 2,53; 
$95 \% \mathrm{Cl} 1,57-4,09 ; p<0,001)[10]$. Istotny jest też sam rodzaj zastosowanego drenażu, gdyż jak to wykazał Yeh i wsp. [12], zastosowanie drenażu ssąco-płuczącego zwiększa ryzyko nieszczelności (OR 9,13; 95\%Cl 1,16-71,76). W innym badaniu zastosowanie drenażu zespolenia poprzez dren wprowadzony przez odbyt okazało się być istotnym, niezależnym czynnikiem ryzyka (OR 3,51; 95\%Cl 1,46-8,39; $p=0,005$ ) [19]. Odmienne wyniki dotyczące drenażu zespolenia przez odbyt przedstawiają autorzy japońscy, którzy w grupie chorych z drenażem zaobserwowali znacząco niższy odsetek NZ niż u chorych bez drenażu: 2,7\% vs 15,7\%, p = 0,04 [41]. Badanie miało jednak charakter retrospektywny i było przeprowadzone na małej liczebnie grupie chorych $(n=176)$. Z przeprowadzonej analizy piśmiennictwa wynika zatem, iż należy zdrenować miednicę, używając do tego np. drenu Penrosa lub innego drenażu biernego, zaś drenowania samego zespolenia przez odbyt może budzić kontrowersję ze względu na sprzeczność prezentowanych wyników.

\section{Doświadczenie chirurga}

Istotnym czynnikiem ryzyka nieszczelności jest też brak doświadczenia chirurga $w$ leczeniu operacyjnym raka odbytnicy (OR 4,12; 95\%Cl 1,48-11,49; p = 0,007) [19]. W wielu badaniach wykazano znaczenie specjalizacji chirurga w przełożeniu na wyniki leczenia [40, 42-45]. Pytaniem otwartym pozostaje, kogo należałoby uznać za specjalistę w leczeniu operacyjnym chorych na raka odbytnicy. Gdyby przyjąć standardy proponowane przez The Association of Coloproctology of Great Britain and Ireland (ACPGBI), odsetek NZ po resekcji przedniej wykonanej przez specjalistę w dziedzinie chirurgii jelita grubego nie powinien przekraczać 8\%. Niezależnie jednak od tego, jakie kryteria przyjmiemy dla określenia, kto jest specjalistą w tej dziedzinie, operacji chorych na raka odbytnicy powinni podejmować się chirurdzy dysponujący odpowiednio dużym doświadczeniem.

\section{Kiedy wyłonić zabezpieczającą stomię?}

Spośród wszystkich analizowanych parametrów 22 zostały wyodrębnione metodą analizy wieloparametrycznej, jako niezależne czynniki ryzyka NZ po resekcji przedniej. Były to: płeć męska, położenie guza $\leq 10 \mathrm{~cm}$ od brzegu odbytu, palenie tytoniu, radioterapia/radiochemioterapia przedoperacyjna, choroba niedokrwienna serca, wiek > 60 lat, cukrzyca, obturacyjne/restrykcyjne choroby płuc, okrężny guz, guz o wymiarach $>3,5 \mathrm{~cm}$, niskie położenie zespolenia, rekonstrukcja ze zbiornikiem J-pouch, powikłania śródoperacyjne, brak drenażu miednicy, drenaż ssąco-płuczący miednicy, drenaż zespolenia przez odbyt, cecha pT4, śródoperacyjna utrata krwi, przetaczanie krwi, złe oczyszczenie jelita, krótki margines dystalny, uwolnienie lewego zagięcia okrężnicy. Już pobieżna analiza tych wyników pozwala zauważyć, że waga poszczególnych czynników jest różna. Niestety, heterogenność materiału i brak surowych danych nie pozwoliły na przeprowadzenie metaanalizy na podstawie zgromadzonego piśmiennictwa. Warto jednak zauważyć, że $\mathrm{w}$ analizowanych publikacjach najczęściej identyfikowanymi, niezależnymi czynnikami ryzyka NZ były: niskie położenie guza i/lub niskie położenie zespolenia, śródoperacyjna utrata krwi i/lub przetoczenie krwi, radioterapia przedoperacyjna, płeć męska, cukrzyca, palenie tytoniu oraz obturacyjna/restrykcyjna choroba płuc (tylko przy zespoleniu koloanalnym) (tab. IV). Praktyka kliniczna uczy jednak, że nie wszyscy chorzy z nisko położonym guzem, po niskiej resekcji przedniej czy też po radioterapii przedoperacyjnej wymagają wyłonienia zabezpieczającej stomii, chociaż wyniki większości analizowanych prac wskazują, iż brak zabezpieczającej stomii zwiększa ryzyko NZ [8, 10, 11, $14,15,18,19,22,24,28]$. Znane są wyniki 5 randomizowanych badań klinicznych, których pierwszoplanowym celem było określenie znaczenia prewencyjnej stomii u chorych po niskiej resekcji przedniej [2,46-49]. Jedynie dwa z nich wykazują istotnie mniejszy odsetek objawowych NZ w grupie chorych z wyłonioną ileostomią zabezpieczającą [2, 49]. Odsetek reoperacji był znacząco większy jedynie w jednym badaniu [2]. Żadne nie wykazało, aby śmiertelność pooperacyjna w grupie chorych bez zabezpieczającej stomii była znacząco większa. Co więcej, gdy autorzy jednego z cytowanych badań z randomizacją porównali odsetek nieszczelności widocznych w obrazie radiologicznym (bez względu na obecność bądź brak objawów klinicznych), okazało się, że był on podobny w obu grupach (37\% vs 42\%) [47]. Czy możemy więc już dziś odpowiedzieć na pytanie: kiedy zabezpieczająca stomia jest faktycznie potrzebna? Sama identyfikacja bardziej lub mniej istotnych czynników ryzyka NZ nie pozwala odpowiedzieć na to pytanie. Poza omówionymi istnieją też inne parametry rozpatrywane jako czynniki wpływające na ryzyko nieszczelności, które nie zostały tutaj uwzględnione. Wymienić tu można chociażby niektóre leki sterydowe i niesterydowe leki przeciwzapalne czy też wpływ objętości przetaczanych okołooperacyjnie płynów [32, 50, 51]. Konieczna jest zatem kontynuacja badań, które zmierzałyby do tego, aby wyselekcjonować tą grupę chorych, u których niskie zespolenie okrężniczo-odbytnicze (zdefiniowane jako zespolenie w odległości nie większej niż $6 \mathrm{~cm}$ od brzegu odbytu) musi być zabezpieczone stomią. Zdaniem autorów niniejszej publikacji kluczem do dalszych rozważań powinno być przypisanie znanym już czynnikom ryzyka odpowiedniej wartości punktowej i stworzenie w ten sposób „indeksu ryzyka nieszczelności”, jak to zaproponowali Liu i wsp. [31]. Stworzona w ten sposób skala ryzyka nieszczelności zespolenia, oparta o znane czynniki predykcyjne, mogłaby posłużyć jako narzędzie badawcze w dalszych dociekaniach. Projekt wieloośrodkowego badania zmierzającego do opracowania takiej skali został zaprezentowany w maju bieżącego roku na XX Zjeździe Polskiego Towarzystwa Chirurgii Onkologicznej. 
Tabela IV. Niezależne czynniki ryzyka nieszczelności zespolenia

\begin{tabular}{|c|c|c|}
\hline Czynnik ryzyka nieszczelności & $\begin{array}{l}\text { Liczba publikacji uwzględniających } \\
\text { w analizie określony czynnik ryzyka }\end{array}$ & $\begin{array}{l}\text { Liczba i odsetek publikacji, w których określony } \\
\text { czynnik ryzyka był niezależny od pozostałych }\end{array}$ \\
\hline \multicolumn{3}{|l|}{ znane przed operacją } \\
\hline — płeć męska & 25 & $7(28 \%)$ \\
\hline — wiek & 24 & $2(8 \%)$ \\
\hline- guz $\leq 10 \mathrm{~cm}$ od brzegu odbytu & 16 & $4(25 \%)$ \\
\hline — radioterapia przedoperacyjna & 17 & $4(24 \%)$ \\
\hline — palenie tytoniu & 12 & $2(17 \%)$ \\
\hline - cukrzyca & 11 & $2(18 \%)$ \\
\hline — choroba niedokrwienna serca & 9 & $1(11 \%)$ \\
\hline \multicolumn{3}{|l|}{ występujące w trakcie operacji } \\
\hline — niskie położenie zespolenia & 12 & $7(58 \%)$ \\
\hline — śródoperacyjna utrata krwi/krwawienie & 12 & $5(42 \%)$ \\
\hline — rekonstrukcja ze zbiornikiem J-pouch & 10 & $1(10 \%)$ \\
\hline — przetoczenie krwi & 7 & $5(71 \%)$ \\
\hline — wielkość guza & 6 & $1(17 \%)$ \\
\hline \multicolumn{3}{|c|}{ inne okołooperacyjne czynniki ryzyka uwzględnione w pojedynczych publikacjach } \\
\hline — obturacyjne/restrykcyjne choroby płuc & 3 & $1(-)$ \\
\hline — powikłania śródoperacyjne & 2 & $2(-)$ \\
\hline — uwolnienie lewego zagięcia okrężnicy & 2 & $1(-)$ \\
\hline —okrężny guz & 1 & $1(-)$ \\
\hline — brak drenażu miednicy & 1 & $1(-)$ \\
\hline — drenaż ssąco-płuczacy miednicy & 1 & $1(-)$ \\
\hline — drenaż zespolenia przez odbyt & 1 & $1(-)$ \\
\hline - cecha pT4 & 1 & $1(-)$ \\
\hline — złe oczyszczenie jelita & 1 & $1(-)$ \\
\hline — krótki margines dystalny & 1 & $1(-)$ \\
\hline
\end{tabular}

\section{Konflikt interesu: nie zgłoszono}

\section{Dr hab. n. med. Andrzej Rutkowski}

Oddział Zabiegowy Kliniki Gastroenterologii Onkologicznej Centrum Onkologii — Instytut im. Marii Skłodowskiej-Curie ul. Roentgena 5, 02-781 Warszawa

e-mail:az.rutkowski@onet.eu

Otrzymano: 3 lipca $2014 \mathrm{r}$.

Przyjęto do druku: 3 września 2014 r.

\section{Piśmiennictwo}

1. Fujita F, Torashima Y, Kuroki T i wsp. The risk factors and predictive factors for anastomotic leakage after resection for colorectal cancer: reappraisal of the literature. Surg Today 2014; 44: 1595-1602.

2. Matthiessen $P$, Hallböök $O$, Rutegård J i wsp. Defunctioning stoma reduces symptomatic anastomotic leakage after low anterior resection of the rectum for cancer: a randomized multicenter trial. Ann Surg 2007; 246: 207-214.

3. Hüser N, Michalski CW, Erkan Mi wsp. Systematic review and meta-analysis of the role of defunctioning stoma in low rectal cancer surgery. Ann Surg 2008; 248: 52-60.

4. Chen J, Wang DR, Yu HF i wsp. Defunctioning stoma in low anterior resection for rectal cancer: a meta- analysis of five recent studies. Hepatogastroenterology 2012; 59: 1828-1831.

5. Tan WS, Tang CL, Shi L i wsp. Meta-analysis of defunctioning stomas in low anterior resection for rectal cancer. Br J Surg 2009; 96:462-472.
6. Snijders HS, van den Broek CB, Wouters MW i wsp. An increasing use of defunctioning stomas after low anterior resection for rectal cancer. Is this the way to go? Eur J Surg Oncol 2013; 39: 715-720.

7. Kapiteijn E, Marijnen CA, Nagtegaal ID i wsp. Preoperative radiotherapy combined with total mesorectal excision for resectable rectal cancer. NEngl J Med 2001; 345: 638-646.

8. Law WI, Chu KW, Ho JW i wsp.Risk factors for anastomotic leakage after low anterior resection with total mesorectal excision. Am J Surg 2000; 179: 92-96.

9. Matthiessen P, Hallböök O, Andersson M i wsp. Risk factors for anastomotic leakage after anterior resection of the rectum. Colorectal Dis 2004; 6: 462-469.

10. Peeters KC, Tollenaar RA, Marijnen CA i wsp. Risk factors for anastomotic failure after total mesorectal excision of rectal cancer. Br J Surg 2005; 92: 211-216.

11. Eriksen MT, Wibe A, Norstein J i wsp. Norwegian Rectal Cancer Group. Anastomotic leakage following routine mesorectal excision for rectal cancer in a national cohort of patients. Colorectal Dis 2005; 7: 51-57.

12. Yeh $C Y$, Changchien $C R$, Wang JY i wsp. Pelvic drainage and other risk factors for leakage after elective anterior resection in rectal cancer patients: a prospective study of 978 patients. Ann Surg 2005; 241:9-13.

13. Kruschewski M, Rieger H, Pohlen U i wsp. Risk factors for clinical anastomotic leakage and postoperative mortality in elective surgery for rectal cancer. Int J Colorectal Dis 2007; 22: 919-927.

14. Eberl $\mathrm{T}$, Jagoditsch $\mathrm{M}$, Klingler A i wsp. Risk factors for anastomotic leakage after resection for rectal cancer. Am J Surg 2008; 196: 592-598.

15. Jestin P, Påhlman L, Gunnarsson U. Risk factors for anastomotic leakage after rectal cancer surgery: a case-control study. Colorectal Dis 2008: 10: 715-721.

16. Lee WS, Yun SH, Roh YN i wsp. Risk factors and clinical outcome for anastomotic leakage after total mesorectal excision for rectal cancer. World J Surg 2008; 32: 1124-1129. 
17. Jung SH, Yu CS, Choi PW i wsp. Risk factors and oncologic impact of anastomotic leakage after rectal cancer surgery. Dis Colon Rectum 2008; 51: 902-908.

18. Bertelsen CA, Andreasen AH, Jørgensen T i wsp. Anastomotic leakage after anterior resection for rectal cancer: risk factors. Colorectal Dis 2010; 12: 37-43.

19. Cong ZJ, Fu CG, Wang HT i wsp. Influencing factors of symptomatic anastomotic leakage after anterior resection of the rectum for cancer. World J Surg 2009; 33: 1292-1297.

20. Tsikitis VL, Larson DW, Poola VP i wsp. Postoperative morbidity with diversion after low anterior resection in the era of neoadjuvant therapy: a single institution experience. J Am Coll Surg 2009; 209: 114-118.

21. Peng J, Lu J, Xu Y i wsp. Standardized pelvic drainage of anastomotic leaks following anterior resection without diversional stomas. Am J Surg 2010; 199: 753-758.

22. Wang $L, G u J$. Risk factors for symptomatic anastomotic leakage after low anterior resection for rectal cancer with $30 \mathrm{~Gy} / 10 \mathrm{f} / 2 \mathrm{w}$ preoperative radiotherapy. World J Surg 2010; 34: 1080-1085.

23. Akasu T, Takawa M, Yamamoto S i wsp. Risk factors for anastomotic leakage following intersphincteric resection for very low rectal adenocarcinoma. J Gastrointest Surg 2010; 14: 104-111.

24. Warschkow R, Steffen T, Thierbach J i wsp. Risk factors for anastomotic leakage after rectal cancer resection and reconstruction with colorectostomy. A retrospective study with bootstrap analysis. Ann Surg Oncol 2011; 18: 2772-2782.

25. Kumar A, Daga R, Vijayaragavan P i wsp. Anterior resection for rectal carcinoma - risk factors for anastomotic leaks and strictures. World J Gastroenterol 2011; 17: 1475-1479.

26. Shiomi A, Ito $\mathrm{M}$, Saito $\mathrm{N}$ i wsp. Diverting stoma in rectal cancer surgery. A retrospective study of 329 patients from Japanese cancer centers. Int J Colorectal Dis 2011; 26: 79-87.

27. Piecuch J, Wiewiora M, Jopek J i wsp. Mortality and anastomotic leakage after anterior resection for rectal cancer. Hepatogastroenterology 2012; 59: 721-723.

28. Smith JD, Butte JM, Weiser MR i wsp. Anastomotic leak following low anterior resection in stage IV rectal cancer is associated with poor survival. Ann Surg Oncol 2013; 20: 2641-2646.

29. Bennis M, Parc Y, Lefevre JH i wsp. Morbidity risk factors after low anterior resection with total mesorectal excision and coloanal anastomosis: a retrospective series of 483 patients. Ann Surg 2012; 255: 504-510.

30. Folkesson J, Brown SS, Gunnarsson U i wsp. Randomised multicentre trial of circular stapling devices. Int J Colorectal Dis 2012; 27: 227-232.

31. Liu Y, Wan X, Wang G i wsp. A scoring system to predict the risk of anastomotic leakage after anterior resection for rectal cancer. J Surg Oncol 2014; 109: 122-125.

32. Boesen AK, Maeda Y, Rørbaek Madsen M. Perioperative fluid infusion and its influence on anastomotic leakage after rectal cancer surgery: implications for prevention strategies. Colorectal Dis 2013; 15: e522-7.

33. Smith JD, Butte JM, Weiser MR i wsp. Anastomotic leak following low anterior resection in stage IV rectal cancer is associated with poor survival. Ann Surg Oncol 2013; 20: 2641-2646.

34. Jorgensen LN, Kallehave F, Christensen E i wsp. Less collagen production in smokers. Surgery 1998; 123: 450-455.
35. Improved survival with preoperative radiotherapy in resectable rectal cancer. Swedish Rectal Cancer Trial. N Engl J Med 1997; 336: 980-987.

36. Randomized study on preoperative radiotherapy in rectal carcinoma. Stockholm Colorectal Cancer Study Group. Ann Surg Oncol 1996; 3: 423-430.

37. Hallböök O, Påhlman L, Krog M i wsp. Randomized comparison of straight and colonic J pouch anastomosis after low anterior resection. Ann Surg 1996; 224: 58-65.

38. Machado M, Nygren J, Goldman Si wsp. Similar outcome after colonic pouch and side-to-end anastomosis in low anterior resection for rectal cancer: a prospective randomized trial. Ann Surg 2003; 238: 214-220.

39. Ho YH, Brown S, Heah SM i wsp Comparison of J-pouch and coloplasty pouch for low rectal cancers: a randomized, controlled trial investigating functional results and comparative anastomotic leak rates. Ann Surg 2002; 236: 49-55.

40. Cirocchi R, Trastulli S, Farinella E i wsp. High tie versus low tie of the inferior mesenteric artery in colorectal cancer: a RCT is needed. Surg Oncol 2012; 21: e111-23.

41. Nishigori $H$, Ito $M$, Nishizawa Y i wsp. Effectiveness of transanal tube for prevention of anastomotic leakage after rectal cancer surgery. World J Surg 2014; 38: 1843-1851.

42. Meagher AP. Colorectal cancer: is the surgeon a prognostic factor? A systematic review. Med J Aust 1999; 171: 308-310.

43. Landheer ML, Therasse $P$, van de Velde $C J$. The importance of quality assurance in surgical oncology. Eur J Surg Oncol 2002; 28: 571-602.

44. Anwar S, Fraser S, Hill J. Surgical specialization and training - its relation to clinical outcome for colorectal cancer surgery. J Eval Clin Pract 2012; 18: 5-11.

45. Borowski DW, Kelly SB, Bradburn DM i wsp. Impact of surgeon volume and specialization on short-term outcomes in colorectal cancer surgery. Br J Surg 2007; 94: 880-889.

46. Graffner $\mathrm{H}$, Fredlund $\mathrm{P}$, Olsson $\mathrm{SA}$ i wsp. Protective colostomy in low anterior resection of the rectum using the EEA stapling instrument. A randomized study. Dis Colon Rectum 1983; 26: 87-90.

47. Pakkastie TE, Ovaska JT, Pekkala ES i wsp. A randomised study of colostomies in low colorectal anastomoses. Eur J Surg 1997; 163: 929-933.

48. Pimentel JM Duarte A Patricio J. The role of a protecting stoma in low anterior resection with TME and colonic J-pouch for rectal cancer; results of a prospective randomized trial. Colorectal Dis 2003; 5 (suppl.2): 83 .

49. Chude GG, Rayate NV, Patris V i wsp. Defunctioning loop ileostomy with low anterior resection for distal rectal cancer: should we make an ileostomy as a routine procedure? A prospective randomized study. Hepatogastroenterology 2008; 55 : 1562-1567.

50. Lake JP, Firoozmand E, Kang JC i wsp. Effect of high-dose steroids on anastomotic complications after proctocolectomy with ileal pouch-anal anastomosis. J Gastrointest Surg 2004; 8: 547-551.

51. Gorissen KJ, Benning D, Berghmans T i wsp. Risk of anastomotic leak age with non-steroidal anti-inflammatory drugs in colorectal surgery. BrJ Surg 2012; 99: 721-727. 